\title{
Impact of Tax Exemptions on the Attractiveness of FDI - The case study of Morocco
}

\author{
RAFIQ Abdelkader ${ }^{1}$ and ALAOUI Omari Lalla Zhor ${ }^{2}$ \\ ${ }^{1,2}$ Research Scholar in Finance and Accounting Management \\ Faculty of Economic and Social Legal Sciences Kénitra \\ Maamora University Campus BP: 2010, \\ Kenitra, Morocco
}

\begin{abstract}
Morocco is resolutely committed to a policy that seeks to make investment both national and foreign, strategic support for economic and social growth, through the implementation of institutional, economic, legislative and regulation.

Improving the business climate, focusing in particular on the adoption of tax exemptions has fostered the inflow of Foreign Direct Investment (FDI).

Empirical studies have explained the close connection between attractive taxation and inflows massif des (FDI), an important vector of globalization, which is currently experiencing considerable development.

The results of this policy are no longer expected, and in the light of the reports published these in recent years by UNCTAD and the exchange office, Morocco has received 23\% of FDI intended in the African country and is among the top five destinations in Africa and first African country francophone.
\end{abstract}

Keywords: Business Climate, Tax Incentives, Direct Foreign. Investments.

\section{INTRODUCTION}

The attractiveness of foreign capital has, for years, been the main concern of Moroccan decision-makers due to the economic variations that result from it.

Several studies have been developed to highlight the factors acting in the ability of a territory to capture external locomotive development.

Resources Morocco has been engaged for more than a decade in reforms aimed at improving the environment, in which economic operators operate.

Thus, the promotion of foreign direct investment (FDI) constitutes a transverse axis for the upgrading and development of the Moroccan economy. In this sense, Morocco has developed an effective strategy for attracting FDI, which today allows it to position among the best African recipients in this component, According to the Report of the Economic and Social Council.

Variables influencing attractiveness are many and varied. Indeed and to encourage investments and support certain promising sectors of the national economy, Morocco endeavored to create a favorable business climate, the consolidation of the partnership between private and public sectors through the adoption of a series of incentives based on an institutional framework and on incentives.

In addition to the tax exemptions granted under common law, the regulations Moroccan provides specific financial and customs advantages granted to investors within the framework of investment conventions, or contracts to be concluded with the State if they meet certain specific criteria.

In this article, we will try to shed light on the interaction of tax as a means of fiscal policy in order to attract foreign investment and the economic creation. This brings us to pose the following problem:

To what extent does tax leverage positively affect the attractiveness of foreign capital

in Morocco?

The research objectives are presented as follows: 
Stressing the role of exemptions and tax incentives on development Economy. - Is the tax tool sufficient to influence the attractiveness of FDI?

The study methodology:

In order to understand these questions, we opted for a methodology on the approach "Positivist" of its founder of Auguste Comte. To do this, the first part of this article will be reserved to define the attractiveness, its determinants and the flagship fiscal measures to encourage FDI, and the second part reflected the impact of incentives on investment behavior and deductions there is related. Conceptual framework, determinants of FDI and Incentive policy The presence of foreign entrepreneurs in Morocco dates back to the middle of the 19th century. However, the question of the foundations of Morocco's attractiveness for foreign capital is a relatively new phenomenon, that has grown in importance in the early years 1990. Indeed, until the eighties,

Indeed, it coincides with the emergence of globalization. This new context that today all countries seek to strengthen their attractiveness potential. This process reinforces the pressure exerted by foreign companies on the host country. The territorial attractiveness of foreign capital is a complex issue and its criteria are varied. The objective is serious, it is to make Morocco an emerging country, capable of not only achieve self-sufficiency in all-round products, but also make the country a benchmark for promoting FDI.

\section{DEFINITION OF ATTRACTIVENESS}

According to the OECD, the attractiveness of territories can be defined as 'the ability to attract skilled and skilled workforce as a means to foster development economic and urban regeneration". Other authors have brought a new approach of the notion of attractiveness of territories; this is Pierre VELTZ, which defines attractiveness as a complex concept applicable to territories.

For Fabrice Hatem (2004), attractiveness is defined as 'the ability of a territory for a given period to attract all kinds of activities factors and mobile factors of production (companies, professional events, Entrepreneurs, capital etc.)

This must take into account the interactions between industrial globalization, metropolitanization and the mode of organization of firms.

\subsection{Definition of exemption:}

The tax exemption, sometimes also called tax exemption, is essentially an exemption from paying a tax imposed by law in certain cases, on natural persons or legal persons (French dictionary).

The exemption is a tax measure, which can take several forms such as the exemption to pay the same or full tax in order to reduce the tax burden. It represents the best tax incentive to promote the inflow of foreign capital Morocco ,is looking for ways to improve its economy in the face of International economic changes, investment incentives and attractiveness are at the heart of the economic policies of the various governments which have succeeded.

Morocco is looking for ways to improve its economy in the face of international economic changes; investment incentives and attractiveness are at the heart of the economic policies of the various governments, which have succeeded.

Territorial attractiveness is a complex issue, its determining criteria are varied and relative, and it has become a new form of competition between territories.

This interest in FDI in an economic context as delicate as that currently crossed by the world is motivated by several endogenous and exogenous order parameters.

It is clear that countries are trying to attract foreign firms with the prospect of develop sectors of activity necessary for their economic and social growth.

Likewise, foreign capital is seen as an effective solution for countries registering macroeconomic difficulties, such as a large shortfall in savings interior, high unemployment, great poverty, and inability to acquire new technologies.

Benefiting from foreign knowledge is a boon for the nation.

So, what are the criteria for attractiveness of FDI that encourage investment in our territory?

Improving the policies and behavior of the public authorities that shape the investment climate is of fundamental importance in stimulating growth and captivity of foreign capital, the impact of which is notable in many fields.

How to attract multinational firms has become a central question in economic policies in many countries?

A growing number of specialists remain divided on the determinants of the attractiveness of FDI. The factors are varied and relative according to the sectors of activity, the countries and the continent. The $2016 \mathrm{CMC}$ survey of a sample of 200 entities (from professional associations, federations and private companies, from all sectors combined) revealed a list of 14 factors considered the most influential detailed as follows:

1- Quality of infrastructure (from infrastructure to international standards)

2- Geographical location

3- Cost of production factors 
4- Size of the domestic market

5- The fundamentals of the Moroccan economy

6 - Quality of human resources

7- The tax burden

8-Investment incentives (tax exemptions among others)

9- Access to bank financing and land

10-Business environment

11- Exchange rate regime

12- Purchasing power

13- Quality of justice

14 - Level of prevalence of corruption

To these influencing factors in the orientation of investors, the political stability of a nation constitutes a pledge for the location of international firms.

It is necessary to recognize the tax burden very high compared to other advantages of the country reception (political and macroeconomic stability, market access, cost reduction due Public business support programs), could discourage investment, especially when the location-specific profit opportunities are limited and thin profit margins.

In Morocco, the tax burden is still high in Morocco. Indeed, according to the new report 2018 of the OECD, the Forum on African Tax Administration (ATAF) and the African Union Commission (AUC), 'Statistics of Government Revenue in Africa', The tax / GDP ratio reached 26.4\% in Morocco in 2016, the third highest ratio in Africa after Tunisia (29.4\%) and South Africa (28.6\%).

A poorly designed tax system could discourage capital investment when rules and their non-transparent, excessively complex or uncertain application come from add to the cost of the project and the uncertainty about net profitability (Thierry LAMRLETTE and Patrick RASSAT).

\subsection{FDI incentive policy:}

Regarding the contribution of foreign direct investment (FDI) to growth economic, Morocco gives an important place to the analysis of the policy and the framework legal and institutional aspects of investment and measures and mechanisms aimed at attracting foreign capital in line with national economic development objectives.

Morocco has developed an effective strategy for attracting FDI, which allows it today to position itself among the best African countries' recipients of this type investment.

The investment promotion strategy in Morocco is summarized as follows: 


\begin{tabular}{|c|c|}
\hline Eligibility & $\begin{array}{l}\text { Companies benefiting from this investment program, responding to one or more } \\
\text { following criteria: } \\
\text {-Invest an amount equal to or greater than nearly } \$ 27 \text { Million ( } 200 \text { Million DHs), } \\
\text {-Create a number of stable jobs equal to or greater than } 250 \text {; } \\
\text { - carry out the project in one of the provinces or prefectures provided for by decree } n{ }^{\circ} 2-98 \text { - } \\
520, \text { June } 30,1998 \text {; } \\
\text {-Ensure technology transfer; } \\
\text {-Contribute to environmental protection. }\end{array}$ \\
\hline Other provisions & $\begin{array}{l}\text { The advantages provided above can be cumulated without however the total participation of } \\
\text { the State exceeds } 5 \% \text { of the total amount of the investment program. } \\
\text { When the investment project is planned in a suburban or rural area or when is an investment } \\
\text { in the spinning, weaving or finishing of textile, state participation can reach } 10 \% \text { of the total } \\
\text { amount of the program investment. }\end{array}$ \\
\hline $\begin{array}{l}\text { Amount Program } \\
\text { Investment }\end{array}$ & $\begin{array}{l}\text { The total cost, all taxes included, of any operation to create or extend activities including } \\
\text { study costs, research and process development costs, costs of land and internal and external } \\
\text { infrastructure, buildings and civil engineering, property of equipment, materials and tools, } \\
\text { taxes, interbank interest, funds turnover and including financial charges. If applicable, any } \\
\text { acquisition or renewal of capital goods, for the production of goods or services, promoting } \\
\text { economic development and creating stable jobs. }\end{array}$ \\
\hline $\begin{array}{l}\text { Transfer from } \\
\text { Technology }\end{array}$ & $\begin{array}{l}\text { Any acquisition or rental of invention, license or process patents techniques to participate in } \\
\text { strengthening competitiveness and research scientist. }\end{array}$ \\
\hline $\begin{array}{l}\text { Protection of } \\
\text { The environment }\end{array}$ & $\begin{array}{l}\text { Any operation to improve environmental protection conditions independently of actions to } \\
\text { remove or reduce nuisances linked to nature of the activity }\end{array}$ \\
\hline $\begin{array}{l}\text { External } \\
\text { infrastructure }\end{array}$ & $\begin{array}{l}\text { All equipment, off-site, of the project support land in road networks, sanitation, water supply, } \\
\text { electricity or telephony. Wastewater treatment plant and earthworks, sewage treatment plant } \\
\text { and earthworks... }\end{array}$ \\
\hline Completion time & The deadlines are fixed in the investment contract. \\
\hline $\begin{array}{l}\text { Payment of } \\
\text { Holdings }\end{array}$ & $\begin{array}{l}\text { After service done, and according to a schedule provided for in the specific contract, against } \\
\text { production supporting documents. }\end{array}$ \\
\hline
\end{tabular}

\section{Source: The National Investment Commission of Morocco}

There are incentives and exemptions in the General Tax Code and the Code customs and indirect taxes so in the finance laws voted annually in the parliament.

Thus, the reforms undertaken have enabled it to open up to the market international, so many assets to lure companies to inject their money into Moroccan soil.

The main tax reforms in Morocco, until 2014, aim to stimulate private investment and encourage foreign investors to carry out as well as their projects in Morocco. In view of this analysis, the tax burden constitutes a handicap for a brake on the flow of foreign investment and everyone complains about taxes, and businesses from developing countries are no exception.

The main tax incentives are as follows (General Directorate of Taxes) :

\section{- Customs duty:}

The adoption of a legal framework allowing the granting of customs and fiscal advantages large-scale investment programs, particularly those whose amount exceeds 200 million dirhams.

The simplification of customs procedures in favor of investment through, in particular, the introduction of bonded processing regimes, the granting of facilities for investment goods imported by split shipments and the adoption of selective checks at the time of customs clearance. 


\section{- INCOME TAX - some measures:}

$>$ Total exemption from income tax for 5 years, followed by an allowance of $80 \%$ for the following 20 consecutive years for companies exercising an activity in free zones, for operations between companies installed in the same free export zone and for the operations carried out between companies established in different free export zones (Law of Finance 2012).

$>$ Permanent taxation at the reduced rate of $20 \%$ for mining company's exporters, and those who sell their products to companies that export them after their valuation.

$>$ Temporary taxation at the reduced rate of $20 \%$ for the first five years following the date of the start of their operation, craft businesses 3 and private educational or vocational training establishments.

$>$ Permanent exemption for farmers and / or farms who have a turnover of less than 5,000,000 DH, in respect of their income agricultural.

\section{- CORPORATION TAX:}

$>$ Taxation at the rate of $8 \%$ :

- Option for foreign companies awarded construction contracts or assembly, exercising an activity in Morocco.

$>$ Taxation at the rate of $10 \%$ :

- Option for offshore banks during the first 15 years following the date of approval (i.e. payment of the equivalent in dirhams of 25,000 dollars US per release year from all other taxes and levies on the profits or revenues from these banks)

- For regional or international headquarters with Casablanca Finance City status (CFC) and the representative offices of non-resident companies with this status.

$>$ Total exemption during the first 5 financial years and application of the reduced rate of $8.75 \%$ beyond this period Service companies with CFC status:

$>$ Total exemption during the first 5 financial years and application of the reduced rate of $8.75 \%$ over the next 20 years

- Companies operating in export processing zones

- Transactions carried out between companies located in the same free zone Export (LF 2012)

- Operations carried out between companies located in different free zones Export (LF 2012)

$>$ Taxation at the rate of $15 \%$

- Income from shares, membership shares and similar income

$>$ Taxation at the rate of $17.5 \%$

- Taxable farms benefit from tax at the rate of $17.5 \%$ for the first 5 consecutive years, from the first tax year. So, farmers with annual turnover become taxable at the is greater than or equal to the above-mentioned amounts below (see number 10).

$>$ Permanent total exemption

- Agricultural companies subject to the IS and achieving a turnover of less than 5,000,000 MAD for their agricultural income.

$>$ Temporary exemption

- Progressive taxation for the taxation of large farms achieving a turnover greater than or equal to 5,000,000 MAD, from January 1, 2014. To this end, will continue to benefit from tax exemption on companies:

- From January 1, 2016 until December 31, 2017, farmers who carry out a turnover of less than 20,000,000 MAD;

- From January 1, 2018 until December 31, 2019, farmers who carry out turnover below 10,000,000 MAD.

Farmers can no longer benefit from this exemption after the financial year title of which they became taxable.

$>$ Permanent taxation at the reduced rate of $17.5 \%$

- Exporting mining companies

- Mining companies that sell their products to companies that export them after their valuation.

$>$ Temporary taxation (5 years) at the reduced rate of $17.5 \%$.

- Craft businesses (whose production is the result of work essentially manual)

- Private education and vocational training establishments

- Property developers, legal persons, in respect of income from the rental of cities, residences and university campuses realized within the framework of a convention concluded with the State

- Taxable agricultural companies from the first open tax year and this, from January 1, 2014.

- $\quad$ Sports companies established in accordance with Law No. 30-09

$>$ Taxation at the rate of $20 \%$ 
- $\quad$ Fixed income investment products

$>$ Abatement from general income tax.

- The common law system provides for an exemption from IGR for companies, exporting products or services, which achieve export turnover during the first 5 years (with a rate between 13 and $44 \%$ from an annual income of 20,000 MAD according to Law No. 17- 89 on the general income tax), then a reduction of 50\% of this tax beyond the aforementioned period.

$>$ Dividend tax exemption stocks, shares and similar income - $10 \%$ APR excluding ZFE).

$>$ Exemption from VAT for the entry of products into a free zone (excluding EPZ, rate normal of $20 \%$ and reduced rates of $7 \%, 10 \%$ and $14 \%$, with possibilities for exporting companies to benefit from suspensive schemes under the provisions laid down in Articles 9 and 9 bits of Law No 3085 on VAT and by the Investment Charter).

It should however be noted that the advantages granted cannot be combined with other benefits provided by other investment legislation, such as conventional investment charter regime (Article 17). Similarly, the taxation at reduced rates cannot be combined with other tax benefits, but companies have the right to choose the most advantageous tax system.

\section{IMPACT OF TAX INCENTIVES ON THE MOROCCAN ECONOMY}

The analysis of foreign investments in our country reveals four trends strong:

Thus, the reforms undertaken have enabled it to open up to the market international, so many assets to lure companies to inject their money on Moroccan soil.

Likewise, the improved business climate has had a positive impact on flows. Foreign Direct Investment has been recorded (OCDE). Therefore, the Kingdom keeps on climb the ladder of the continent's most attractive African countries.

The stock of foreign direct and portfolio investment in Morocco has reached first semester 2015 an amount of DH 586 billion or $60 \%$ of GDP. It increased by 27 Billion in six months. In a regional environment not conducive to investment, our country has strengthened its attractiveness. It has captured on average 23\% of FDI intended for the country Africa.

For the rating agency " FITCH', our country will always be attractive for FDI in the coming years. Political continuity, positive reforms brought to the climate of business and industry performance are assets to make Morocco a destination privileged of the investors. The subsidiary 'FITCH' recalls besides that the production manufacturing grew $1.4 \%$ in 2016 with a strong contribution from the sector automotive $(+14 \%)$.

Over the past 9 years, the improvement in the business climate has even enabled Morocco to climb 61 places in the Doing Business.

Also, and according to the latest Africa Investment index 2016 from the Swiss firm Quantum Global research, Morocco is one of the top five IDE destinations on the African continent and it is ranked second on the Index just after Botswana.

For Ernst and Young (EY) recently published a report on savings African countries, which places Morocco ahead of South Africa on its level of capture of foreign direct investment. Indeed, with regard to direct investments foreigners, IDE, since 2016, South Africa occupied the first place on the scene Mainland. However, in 2017, Morocco attracted almost 13\% of FDI announced on the continent, the same proportion as that of South Africa. (Diplomatic Morocco -28 Oct 2018).

\section{CONCLUSION}

Territorial attractiveness is placed at the center of the various economic policies engaged by Morocco. Thus, the continuous improvement of the business climate is part of a long-term strategy aimed at providing a favorable environment for investment and therefore captivity of foreign capital.

As a direct consequence of this policy of promoting FDI, Morocco is become a favorite destination for foreign investors in recent years and this is not the result of chance, but of in-depth reform-oriented work engaged in political, fiscal and financial matters.

It is commonly accepted that the tax component has a clear effect on efficiency that prompted our leaders to undertake a series of reforms aimed at make our economy more competitive.

in fact, according to the Report of the Ministry of Finance and Privatization, the various reports from national or foreign organizations highlight the evidence that the fiscal weapon is an influential but not decisive factor in the attractiveness of FDI.

A rentier and corrupt economy, closed and poorly governed characterized by costs higher administrative levels, in particular a discouraging tax system inevitably reduces its attractiveness.

In addition, certain barriers to investment persist and decision-makers are called upon to make the necessary corrections to make Morocco a true champion in matters influx of FDI. 
International Journal of Advances in Scientific Research and Engineering (ijasre), Vol 6 (2), February-2020

Other major impediments to the business climate include, in descending order, access to finance, transportation and ultimately court cases.

\section{BIBLIOGRAPHY}

1. Economic and Social Council Report No 9/2012: The Moroccan tax system -economic and social development

2. Globalization, cities and territories Ed. PUF, 2005,

3. Territorial marketing, MR HATEM Fabrice 2004

4. Book: Thierry LAMRLETTE and Patrick RASSAT: International Tax Strategy

5. The Tax Incentives System: General Directorate of Taxes

6. Strategy of development of the business climate 'Dimension -Politics and Administration"- MENA - OECD program for investment

7. Report Ministry of Finance and Privatization: Diagnosis of the attractiveness of Morocco For Direct Foreign Investment. 